Creative Commons User License: CC BY-NC-ND

Abstracted by: EBSCOhost, Electronic Journals Service (EJS),

Google Scholar, Journal Seek, Scientific Commons,

Food and Agricultural Organization (FAO), CABI and Scopus

http://eoi.citefactor.org/10.11226/v25i4
Journal of Agricultural Extension

Vol. 25 (4) October, 2021

ISSN(e): 24086851; ISSN(Print); 1119944X

http://journal.aesonnigeria.org

http://www.ajol.info/index.php/jae

Email: editorinchief@aesonnigeria.org

\title{
Traditional Salt Processing Activities of Rural Women in Ebonyi State, Nigeria
} https://dx.doi.org/10.4314/jae.v25i4.8

\section{Iwuchukwu, Juliana Chinasa}

Department of Agricultural Extension

University of Nigeria, Nsukka, Enugu State, Nigeria

Email: juliana.iwuchukwu@unn.edu.ng; Phone: +234 8063276459

\section{Attamah, Clement Okechukwu}

Department of Agricultural Extension

University of Nigeria, Nsukka, Enugu State, Nigeria

Email: clement.attamah@unn.edu.ng; Phone: +234 7035397081

\section{Chukwuonu, Charles Ubani}

Department of Agricultural Extension

University of Nigeria, Nsukka, Enugu State, Nigeria

Email: charleschukwuonu@gmail.com; Phone: +234 7068919992

\begin{abstract}
The traditional salt processing activities of rural women in Ebonyi State, Nigeria was investigated. Two Local Government Areas were purposively selected out of the 13 LGAs in the state and a total of 90 respondents were used for the study. Frequency, percentage and mean score were used in data analysis. Most (68\%) of the respondents belonged to salt makers group. The majority (98.9\%) of the salt makers indicated that their method of salt production involved pan evaporation with firewood. About $63 \%$ of the salt makers engaged in salt production during the dry season. A greater percentage (63.2\%) indicated that they fetch brine as the need arises. The majority (86.6\%) indicated using ash to filter the brine, while the majority (97.2\%) reported that it takes less than 1 day to produce filtrate. About $67 \%$ of the women produced 6-10 bags of salt in a month while $53.4 \%$ sold 7-10 bags in a month. Salt makers sold salt at an average price of $\mathrm{A} 3,650$ per bag. Findings show that $24.7 \%$ earned N10,000- N19,999 per month. Major contributions of salt making to the wellbeing of households were: medicinal value $(M=2.96)$, payment of children/ward school fees $(M=2.96)$, better feeding and nutrition ( $M=2.93)$. Government should provide aids to the salt processors by providing the basic infrastructure to improve the quality and quantity of salt produced.
\end{abstract}

Keywords: Salt processing, Rural women, Ebonyi State

\section{Introduction}

In every rural setting, there are livelihood strategies of the people. In Ebonyi State, salt processing using traditional method happens to be a means of making ends meet especially among rural women due to large salt deposit in the land (Oginiyi, 2019). This method of salt processing has continued for about 400 years in the area 
Creative Commons User License: CC BY-NC-ND

Abstracted by: EBSCOhost, Electronic Journals Service (EJS),

Google Scholar, Journal Seek, Scientific Commons,

Food and Agricultural Organization (FAO), CABI and Scopus

http://eoi.citefactor.org/10.11226/v25i4
Journal of Agricultural Extension

Vol. 25 (4) October, 2021

ISSN(e): 24086851; ISSN(Print); 1119944X

http://journal.aesonnigeria.org

http://www.ajol.info/index.php/iae

Email: editorinchief@aesonnigeria.org

(Nigeria Galleria, 2021) with no obvious scientific information as per how the rural women conduct their activities. All that is available are mainly newspaper reportages on issues like cultural uses of salt and oral interview reports that lacked scientific procedures (Agbeze, 2019; Nigeria Galleria, 2021). Empirical details on method of processing adopted, season of production, brine handling, quantity produced, amount earned from product and contribution of salt making to households' wellbeing are unknown.

The need to have a systematic and scientific overview of what salt processing is in the area is very crucial. This is because no rural community develops when the livelihood means of her people are not being projected in a better light such that it can attract either local or foreign interventions. Also, the essentiality of salt to homes and industries demands that processes around its local production should be uncovered for possible modification or enhancement through well-articulated and organized extension-facilitated training of the people (Nigeria Galleria, 2021). The study identified the salt processing activities and the contribution of salt processing to the wellbeing of households.

\section{Methodology}

The study was carried out in Ebonyi State, Nigeria. It is located between latitude $6^{\circ}$ $15^{i} \mathrm{~N}$ and longitude of $8^{0} 0^{i} \mathrm{E}$. The state shares border with Benue State to the North, Enugu State to the west, Imo and Abia States to the south and Cross River State to the east. It occupies an area of about $6,488 \mathrm{~km}^{2}$ and has an estimated population of 2,880,400 (Brinkhoff, 2020; United States Agency for International Development-USAID, 2017). Ebonyi State is located in the humid tropical rain forest zone. Its temperature is characteristic of a tropical climate with mean daily temperature of about $26^{\circ} \mathrm{C}$ (Time and Date, 2021).

The state is blessed with mineral resources such as lead, limestone, zinc and marble. Ebonyi is called "the salt of the nation" for its huge salt deposit at the towns of Okposi, Uburu and Abakaliki. Women who were involved in salt making in the state constituted the population for the study. Ninety (90) respondents who were into salt making were purposively selected from two LGAs that have abundance of salt reserve in the state. These LGAs are Ikwo and Ohaozara LGAs.

Data for the study were collected through the use of a structured interview schedule, personal observation and key informant interview. The interview schedule contained relevant questions based on each of the specific objectives of the study and was subjected to both content and face validity before deployment.

To identify the salt processing activities, the respondents indicate from a list of those activities in which they engaged in salt making such as techniques used, how to fetch the brine, season of fetching brine, filtering of the brine, boiling of the brine, packaging of the salt, the time spent in filtering, boiling and forming of salt, the 
Creative Commons User License: CC BY-NC-ND

Abstracted by: EBSCOhost, Electronic Journals Service (EJS),

Google Scholar, Journal Seek, Scientific Commons,

Food and Agricultural Organization (FAO), CABI and Scopus

http://eoi.citefactor.org/10.11226/v25i4
Journal of Agricultural Extension

Vol. 25 (4) October, 2021

ISSN(e): 24086851; ISSN(Print); 1119944X

http://journal.aesonnigeria.org

http://www.ajol.info/index.php/jae

Email: editorinchief@aesonnigeria.org

quantity of wood or the cost of wood used to dewater the brine and the number of hours/days spent in processing of salt.

To ascertain the contributions of salt production to the wellbeing of household, a list of variables was presented to the respondents to tick from on a 4-point Likert-type scale with responses as "to a great extent (3), to a moderate extent (2), to a little extent (1), and to no extent (0)". The values on the Likert-type scale gave a mean score of 1.5. Any variable with a mean score higher or equal to 1.5 was regarded as a major contribution of salt making to the wellbeing of households, while a variable with a mean score less than 1.5 was regarded otherwise. These contributions include: feeding, shelter, employment, payment of children/ward school fees, building of houses and title taking. The data generated were subjected to descriptive statistics.

\section{Results and Discussion}

\section{Salt Processing Activities}

Table 1 reveals that the majority (97.8\%) employed pan evaporation using fire wood while $2.2 \%$ employed pan evaporation with solar/sun. Firewood may be the only source of fuel available to the rural natives at all times. The use of firewood as a source of fuel has led to the decimation of mangrove trees and forest and had led to the production of low-quality salt (Agbeze, 2019). Lack of funds or poor access to other sources of energy may be a reason to the resort to this method of salt production. It could also be lack of technical know-how in the use of other methods of production like vacuum evaporation and rock salt mining. Salt produced by pan evaporation had many impurities resulting from the usage of firewood collected from the upland forest. The improved salt production techniques do not require the usage of firewood. Traditional salt producers reported that the use of mangrove wood could provide a better-quality salt compared to the use of firewood collected from the upland forest as the mangrove wood smokes less than firewood extracted from upland forest. Solar evaporation facilities have the capacity to totally eliminate the pollution associated with firewood evaporation if deployed.

Table 1 also shows that the majority (62.9\%) of the respondents preferred to carry out salt processing activities in dry season. This implies that maximum production is carried out in dry season. It may be as a result of high concentration of brine in dry season thereby facilitating timely and speedy production.

Result in Table 1 further reveals that the majority (86.7\%) preferred to fetch brine anytime they felt like, $13.3 \%$ preferred morning, $5.6 \%$ preferred evening while 4.4 preferred afternoon. This could imply that there is no restriction to the accessibility of the lake. The rural women are free to access their natural resources anytime. This could be an advantage as there is unlimited access to its use.

Furthermore, entries in Table 1 reveal that greater proportion (63.2\%) liked to fetch the brine when the need arises, $22.8 \%$ liked to fetch at their convenience, $14 \%$ liked 
Creative Commons User License: CC BY-NC-ND

Abstracted by: EBSCOhost, Electronic Journals Service (EJS), Google Scholar, Journal Seek, Scientific Commons,

Food and Agricultural Organization (FAO), CABI and Scopus

http://eoi.citefactor.org/10.11226/v25i4
Journal of Agricultural Extension

Vol. 25 (4) October, 2021

ISSN(e): 24086851; ISSN(Print); 1119944X

http://journal.aesonnigeria.org

http://www.ajol.info/index.php/jae

Email: editorinchief@aesonnigeria.org

morning because of cool weather. This could imply that there is no restriction to the time of visiting the lake. Hence, any willing producer could make as much as possible. This is unlike situations where resources of common interest are operated under strict regulations; where access is limited.

Table 1: Activities involved in salt processing

\begin{tabular}{ll}
\hline Variables & Percentage $(\mathbf{n}=\mathbf{9 0})$ \\
\hline Method of salt production & \\
Pan evaporation with firewood & 97.8 \\
Pan evaporation with solar/sun & 2.2 \\
Season of production & 62.9 \\
Dry season & 37.1 \\
Any season & \\
Time of fetching brine* & 4.4 \\
Early morning & 13.3 \\
Morning & 4.4 \\
Afternoon & 5.6 \\
Evening & 86.7 \\
Any time & \\
Reasons for fetching brine at time above & 63.2 \\
When the need arises & 22.8 \\
Convenience & 14.0 \\
Cool weather & \\
How to filter brine & 86.6 \\
Use of ash & 5.0 \\
Use of ash and sand & 1.7 \\
Use of ash and palm fruit cake & 6.7 \\
Allow to settle and decant & \\
Days to filtrate & \\
Less than 1 & 97.2 \\
1-3 & 1.4 \\
More than 3 & 1.4 \\
Vessels used to boil brine & \\
Earthen pots & 2.2 \\
Metal pots & 97.8
\end{tabular}

Field survey, 2017

"Multiple response

Additionally, entries in Table 1 show that all the respondents fetched salt water. The majority $(86.6 \%)$ of the respondents used ash in filtering the brine, $6.7 \%$ allowed the brine to settle and decant, $5 \%$ used ash and sand while $1.7 \%$ used ash and palm fruit chaff. This could imply that the respondents make use of the materials in their environment during production process.

The ash is poured at the bottom of the concentrating pot (ofufu) before the introduction of the salty earth to prevent the sand from blocking the opening of 
Creative Commons User License: CC BY-NC-ND

Abstracted by: EBSCOhost, Electronic Journals Service (EJS),

Google Scholar, Journal Seek, Scientific Commons,

Food and Agricultural Organization (FAO), CABI and Scopus

http://eoi.citefactor.org/10.11226/v25i4
Journal of Agricultural Extension

Vol. 25 (4) October, 2021

ISSN(e): 24086851; ISSN(Print); 1119944X

http://journal.aesonnigeria.org

http://www.ajol.info/index.php/jae

Email: editorinchief@aesonnigeria.org

the concentrating pot (ofufu) at the bottom and also palm fruit chaff is also used to ensure effective filtration (Personal observation and key informant report).

Results in Table 1 further show that the majority (97.2\%) of the respondents indicated that it takes less than 1 day to obtain filtrate, $1.4 \%$ indicated that it takes 1 3 days, while $1.4 \%$ indicated that it takes more than 3 days. The World Trade Organization (WTO) has adopted norms that say that salt - in order to have the right to be called "salt" - must contain at least $97 \%$ of Sodium Chloride $(\mathrm{NaCl})$ irrespective of days of filtration but this is not usually the case with many traditionally made salt because of high degree in minor salts and trace elements due to poor filtration process.

Data in Table 1 also show that the majority (97.8\%) use metallic pots to carry out ebullition, while $2.2 \%$ use earthen pots. In contrast, Quora (2021) indicated that the use of metallic boiling (pan) can cause metal pollution of salt due to possible corrosive action of hot liquid brine.

\section{Activities Involved in Salt Production}

Table 2 shows that the majority $(78.9 \%)$ of the respondents employed labour. This could imply that series of activities are involved in salt making. The salt maker depends on employed labour to meet up with the timely discharge of every activity sequentially. This agrees with Agbeze (2021) who states that most of the salt making activities require manual labour and elaborate physical exertion which results in drudgery. The associated drudgery could be eliminated or reduced through the use of machines.

Table 2 shows that the majority $(56.6 \%)$ of the respondents worked $6-7$ times a week, $31.1 \%$ worked $4-5$ times a week, while $12.2 \%$ worked $2-3$ times a week. The mean days of work in a week was 5 days. This could imply that the respondents engage in active production to meet demands. This may also signify the lapses of the local technology and its inefficiency to produce in commercial scale.

Table 2 reveals that the majority (66.7\%) of the respondents produced $6-10$ bags a month, $24.3 \%$ produced $11-15$ bags, and $6.6 \%$ produced $1-5$ bags, while $2.2 \%$ produced above 15 bags. The mean number of bags produced in a month was 9 bags. This is far below world monthly production average of 35,266 bags (United States Geological Survey, 2021). This imply that the majority of the salt farmers are into small scale production. The local technology produces less quantity of salt.

Table 2 shows that the majority (53.4\%) sold $7-10$ bags a month, $42.2 \%$ of respondents sold 3-6 bags a month, while $4.4 \%$ of the respondents sold $11-14$ bags in a month. The mean number of bag sold in a month was 7 bags. This signifies weak market network. It may be attributed to lack of access road, poor 
Creative Commons User License: CC BY-NC-ND

Abstracted by: EBSCOhost, Electronic Journals Service (EJS), Google Scholar, Journal Seek, Scientific Commons,

Food and Agricultural Organization (FAO), CABI and Scopus

http://eoi.citefactor.org/10.11226/v25i4
Journal of Agricultural Extension

Vol. 25 (4) October, 2021

ISSN(e): 24086851; ISSN(Print); $1119944 X$

http://journal.aesonnigeria.org

http://www.ajol.info/index.php/jae

Email: editorinchief@aesonnigeria.org

communication networks and lack of improved product. It could also be tied to obtainable scale of production in the area as sales cannot exceed quantity produced.

Table 2: Activities involved in salt processing

\begin{tabular}{|c|c|c|}
\hline Variable & Percentage $(n=90)$ & Mean $(\bar{x})$ \\
\hline \multicolumn{3}{|l|}{ Labour employment } \\
\hline Yes & 78.9 & \\
\hline \multicolumn{3}{|l|}{ Source of labour* } \\
\hline Family members & 78.9 & \\
\hline Friends & 45.6 & \\
\hline Group members & 1.1 & \\
\hline Hired & 1.1 & \\
\hline \multicolumn{3}{|l|}{ Days of work in a week } \\
\hline $2-3$ & 12.2 & \\
\hline $4-5$ & 31.1 & 5.0 \\
\hline $6-7$ & 56.6 & \\
\hline \multicolumn{3}{|c|}{ No of salt bags produced in a month (bags) } \\
\hline $1-5$ & 6.6 & \\
\hline $6-10$ & 66.7 & \\
\hline $11-15$ & 24.3 & 9.0 \\
\hline Above 15 & 2.2 & \\
\hline \multicolumn{3}{|l|}{ Size of bags produced $(\mathbf{k g})$} \\
\hline $15-20$ & 1.1 & \\
\hline $21-26$ & 1.1 & \\
\hline $27-32$ & 20.0 & 44.06 \\
\hline Above 32 & 1.1 & \\
\hline \multicolumn{3}{|l|}{ No of bags sold in a month } \\
\hline $3-6$ & 42.2 & \\
\hline $7-10$ & 53.4 & 7.26 \\
\hline $11-14$ & 4.4 & \\
\hline \multicolumn{3}{|l|}{ Selling price per bag (Naira) } \\
\hline Below 1,600 & 15.5 & \\
\hline $1,600-3,000$ & 6.6 & \\
\hline $3,100-4,500$ & 71.1 & 3,650 \\
\hline $4,600-6,000$ & 5.5 & \\
\hline Above 6,000 & 1.1 & \\
\hline \multicolumn{3}{|l|}{ Steps in salt making } \\
\hline Fetching of brine & 100.0 & \\
\hline Filtering of brine & 100.0 & \\
\hline Boiling of brine (evaporation) & 100.0 & \\
\hline Harvesting of salt & 100.0 & \\
\hline Packaging of salt & 100.0 & \\
\hline Marketing of salt & 100.0 & \\
\hline
\end{tabular}

Field Survey 2017. *Multiple response

Entries in Table 2 also reveals that the majority $(71.1 \%)$ of the respondents sold a bag at $\mathrm{N} 3,100-\mathrm{N} 4,500,15 \%$ sold per bag of salt below $\mathrm{N} 1600,6.6 \%$ sold at $\mathrm{N} 1600$ N $3000,5.5 \%$ and $1.1 \%$ sold per bag of salt at $\mathrm{N} 4,600-\mathrm{N} 6000$ and above $\mathrm{N} 6000$, respectively. The mean selling price of salt was $\mathrm{N} 3,650$ per bag. Producers are able to compete only in local markets with non-iodized salt. Weak transport infrastructure also favours informal distribution networks. This creates opportunities for middlemen 
Creative Commons User License: CC BY-NC-ND

Abstracted by: EBSCOhost, Electronic Journals Service (EJS), Google Scholar, Journal Seek, Scientific Commons,

Food and Agricultural Organization (FAO), CABI and Scopus

http://eoi.citefactor.org/10.11226/v25i4
Journal of Agricultural Extension

Vol. 25 (4) October, 2021

ISSN(e): 24086851; ISSN(Print); 1119944X

http://journal.aesonnigeria.org

http://www.ajol.info/index.php/jae

Email: editorinchief@aesonnigeria.org

to buy salt from local producers and reach out to larger markets thereby making more profit than the producers.

All the respondents admitted that they took active part in all the steps involved in salt making. These steps are fetching of the brine, filtering of the brine, boiling of the brine(evaporation), harvesting of the salt, packaging of the salt, and marketing of the salt (Table 2). The numerous steps show how stressful it will be for one person to produce salt. Every activity should be meticulously followed to obtain the last product which is salt.

\section{Contribution of Salt Processing to Wellbeing of Households}

Data on Table 3 show that traditional salt production had contributed to the wellbeing of households as can be justified from the following variables: medicinal value $(\bar{x}=2.96)$, payment of children/ward school fees $(\bar{x}=2.96)$, better feeding and nutrition $(\bar{x}=2.93)$, expansion of salt farms $(\bar{x}=2.76)$, expansion of other farm enterprise $(\bar{x}=2.68)$, building of house $(\bar{x}=2.69)$, increase in income $(\bar{x}=2.57)$, title taking $(\bar{x}=2.63)$, purchasing of land $(\bar{x}=2.44)$, generation of capital for occupational diversification $(\bar{x}=2.22)$ and exposure to international bodies $(\bar{x}=1.80)$. These suggest that salt processing had contributed immensely to the growth and development of the people. It could be deduced also that salt making enhanced the standard of living of the producers. As a highly sought article of trade, women judiciously and prudently utilize the proceeds from this investment to support their communities, help pay school fees for their sons and daughters in primary and post primary institutions and take women accredited titles such as Osu, Okwanikpo, Ogbunodu (Agbeze, 2021). 
Creative Commons User License: CC BY-NC-ND

Abstracted by: EBSCOhost, Electronic Journals Service (EJS),

Google Scholar, Journal Seek, Scientific Commons,

Food and Agricultural Organization (FAO), CABI and Scopus

http://eoi.citefactor.org/10.11226/v25i4
Journal of Agricultural Extension

Vol. 25 (4) October, 2021

ISSN(e): 24086851; ISSN(Print); 1119944X

http://journal.aesonnigeria.org

http://www.ajol.info/index.php/jae

Email: editorinchief@aesonnigeria.org

\section{Table 3: Contributions of salt productions to wellbeing of households}

\begin{tabular}{lcl}
\hline Contributions to wellbeing & Mean $(\bar{x})$ & Std. deviation \\
\hline Aids better feeding and nutrition & $2.93^{*}$ & 0.45 \\
Has medicinal value & $2.96^{*}$ & 0.33 \\
Payment of children/ward school fees & $2.96^{*}$ & 0.33 \\
Building of houses & $2.69^{*}$ & 0.59 \\
Create platform for title taking & $2.63^{*}$ & 0.66 \\
Expansion of other farm enterprises & $2.68^{*}$ & 0.75 \\
Expansion of salt business & $2.76^{*}$ & 0.68 \\
Purchasing of cars and other luxury & $1.74^{*}$ & 0.68 \\
Increase in income & $2.57^{*}$ & 0.69 \\
Employment of members of household & $2.76^{*}$ & 0.62 \\
Formation of capital for settlement of dependent relatives & $2.17^{*}$ & 0.84 \\
Purchasing of land & $2.44^{*}$ & 0.75 \\
Formation of capital for occupational diversification & $2.22^{*}$ & 0.79 \\
Formation of capital for participation in politics & 1.31 & 0.96 \\
Increases linkage/interaction with other people and family & $1.71^{*}$ & 0.72 \\
Exposure to international bodies & $1.80^{*}$ & 0.84
\end{tabular}

*Major contributions

\section{Conclusion and Recommendations}

The local technology of salt making involved pan evaporation using firewood as a source of heat, which may have contributed to high impurity level of locally-made salt. The technology is labour intensive and involves series of activities which include fetching of brine, concentrating, filtering, evaporation, harvesting, packaging and marketing. Salt making is a means of livelihood for the rural women and had contributed productively to the wellbeing of households. It is also a perfect means of income and occupational diversification when crops and livestock fail.

Government or NGOs should provide aids to the salt processors by providing the basic infrastructure to improve the quality and quantity of salt produced. These include iodization equipment, gas energy machines, efficient filter systems, packaging equipment, funds and incentives etc. Policies that will give room for interaction and trade relationship between the local salt producers and salt packaging industries in Nigeria can be put in place by government. Salt packaging companies should purchase local salt, improve it and repackage it. Extension in collaboration with other agencies such as WHO, UNICEF etc., should organize onfarm teaching and demonstrations to educate local salt makers on the need to improve their product and how to improve it. Extension should motivate young women so as to develop interest in the occupation to reduce rural-urban migration and reduce unemployment. 
Creative Commons User License: CC BY-NC-ND

Abstracted by: EBSCOhost, Electronic Journals Service (EJS), Google Scholar, Journal Seek, Scientific Commons,

Food and Agricultural Organization (FAO), CABI and Scopus

http://eoi.citefactor.org/10.11226/v25i4
Journal of Agricultural Extension

Vol. 25 (4) October, 2021

ISSN(e): 24086851; ISSN(Print); 1119944X

http://journal.aesonnigeria.org

http://www.ajol.info/index.php/jae

Email: editorinchief@aesonnigeria.org

\section{References}

Agbeze, C. (2019, August 13). Salt-making in Ebonyi. The Sun. https://www.sunnewsonline.com/salt-making-in-ebonyi/

Brinkhoff, T. (2020). Ebonyi State in Nigeria. City Population - Statistics, Maps \& Charts. https://www.citypopulation.de/php/nigeria-admin.php?adm1id=NGA011

Nigeria Galleria (2021). Okposi Salt Lake. https://www.nigeriagalleria.com/Nigeria/States Nigeria/Ebonyi/Okposi-Salt-Lake.html

Oginiyi, N. (2019, November 29). FG set to develop salt deposits in Ebonyi. Business Day. https://www.google.com/amp/s/businessday.ng/uncategorized/article/fg-set-todevelop-salt-deposits-in-ebonyi/amp/

Quora (2021). Does keeping salt in a steel container make it harmful to consume? https://www.quora.com/Does-keeping-salt-in-a-steel-container-make-it-harmful-toconsume

Time and Date (2021). Climate \& weather averages in Ebonyi State, Nigeria. https://www.timeanddate.com/weather/@2595345/climate

United States Agency for International Development (2017). Nigeria population and development-Ebonyi State. Factsheet.

United States Geological Survey (2021). Mineral Commodity Summaries.

https://www.usgs.gov/centers/nmic/mineral-commodity-summaries\#appendixes 